(C2019, Elsevier. Licensed under the Creative Commons Attribution-NonCommercialNoDerivatives 4.0 International http://creativecommons.org/about/downloads

cc) $(1) \Theta$ 


\title{
Scenario Planning, Cognition, and Strategic Investment Decisions in a Turbulent Environment
}

\author{
Riccardo Vecchiato \\ Kingston Business School, Kingston University \\ Kingston, Hill, Kingston upon Thames \\ London, KT2 7LB, UK \\ r.vecchiato@kingston.ac.uk
}

\begin{abstract}
We explore how scenario planning contributes to cognitive dynamics and strategic investment decisions in a changing environment. Our research is based on an in-depth, longitudinal case study of Shell's ventures in Russia between 1994 and 2016. We show that Shell's scenarios did not foresee some major events that occurred in the turbulent Russian energy market. However, the scenarios envisaged the rising role of gas, the strategic relevance of the gas transportation infrastructure, and the growing interventionism of the Russian government. The scenarios thus helped Shell's managers to adapt their strategic beliefs and ultimately enabled them to notice, assess, and respond successfully to external changes - even though these changes had not been foreseen in the scenarios. Shell has been the first (and, for almost a decade, the only) foreign company to produce and export gas from Russia.
\end{abstract}

Keywords: cognition; scenario planning; strategic decision making; organizational adaptation; environmental change. 


\section{Introduction}

Cognitive representations are a critical determinant of managerial decisions and organizational performance (Grewatsch and Kleindienst, 2017; Ocasio et al., 2018). Empirical work has shown that a firm's choice of strategy is often the result of managers' representations of their environment (Barr, 1998; Garud and Rappa, 1994; Kaplan, 2008a).

The extant research regarding managerial cognition focuses primarily on the relationship between strategic beliefs and competition outcomes (Eggers and Kaplan, 2013; Kaplan, 2008b; Tripsas and Gavetti, 2000). Such research showed that, given the influence of prior history, senior managers often struggle to adapt their mental frames in rapidly changing environments, resulting in organizational inertia.

Whereas most scholars have focused on the impact of managerial beliefs on strategic outcomes, others have explored the cognitive dynamics that occur in organizations. These scholars showed that managerial beliefs are not static and that strategic decision making processes can deeply affect their evolution (Garud et al., 2010; Laamanen and Wallin, 2009; Szulanski et al., 2004). In particular, some scholars have focused on the role of scenario planning in informing managerial beliefs (de Geus, 1997; Schoemaker, 2004; Phadnis et al., 2015). In this paper, we build on this latter work by examining how scenarios affect managerial cognition and thus contribute to strategic investment decisions in a turbulent environment.

Our research design is an in-depth, longitudinal case study of a large international corporation, namely, Royal Dutch Shell (hereafter Shell), and its business ventures in Russia. Shell entered this country in the mid-1990s, and since then, it has faced significant changes in the local energy market. To cope with such changes, Shell's managers made an extensive use of scenarios and diligently explored alternative, i.e., opposite, hypotheses about the future evolution 
of the energy industry and the Russian institutional environment. In particular, Shell's scenarios envisaged gas — instead of oil—as the primary energy fuel, the strategic relevance of the gasinstead of the oil - transportation infrastructure, and the growing ambition of the new Putin administration - instead of the friendly support of the previous Yeltsin regime - to control all the local oil and gas reserves. These scenarios thus enabled Shell's managers to adapt their mental models regarding the main sources of competitive advantage (and the barriers to these sources), leading to the emergence of a set of dominant beliefs that ultimately directed their strategic investment decisions. As a result of such beliefs, Shell's managers noticed, interpreted, and reacted more quickly than other foreign energy companies to changes in the Russian energy market, even though these events had not been predicted in the scenarios. Beginning in 2009, Shell has been the first (and, for almost a decade, the only) foreign company to produce and export gas from Russia.

The paper contributes to strategic management knowledge in two areas. First, it expands our understanding of the cognitive dynamics behind the origin and evolution of managerial beliefs (Kaplan, 2011; Mezias et al., 2001). Second, it adds to the study of scenario planning and strategic decision making under uncertainty (Phadnis et al., 2015; Ramirez and Selsky, 2016).

\section{Scenario Planning and Cognition}

\section{Managerial cognition and competition outcomes}

Cognition has long been a mainstream research field in management, as it emphasizes the role of managerial beliefs (i.e., mental models and strategic assumptions) in directing search processes in a new learning environment, the evolution of organizational capabilities, and, 
ultimately, actions and competition outcomes (Laamanen et al., 2018; Walsh 1995). Initial studies date back to the pioneering work of Kiesler and Sproull (1982), who characterize cognition as the process of noticing external stimuli, interpreting them, and incorporating their meaning with other relevant information to make strategic decisions. Subsequent research efforts focused on two cognitive processes that are relevant to strategic decision making: attention and interpretation (Gavetti and Rivkin, 2007; Weick and Sutcliffe, 2007).

Regarding attention, Ocasio (1997: 202) argues that "the ability of the firm to adapt successfully to a changing environment is conditional on whether the firm's procedural and communication channels focus the attention of the organizational decision-makers on an appropriate set of issues and answers." Empirical research has shown that the attentional perspective can explain firms' strategies and actions, such as the speed of response to changes in the industry (Nadkarni and Barr, 2008), the timing of entry into a new product market (Eggers and Kaplan, 2009), or the ability to detect weak signals leading to a crisis (Rerup, 2009).

Concerning the cognitive process of interpretation, Daft and Weick (1984), Jackson and Dutton (1988), and Porac et al. (1995) explore how managers make sense of the abundant and unstructured information that they receive from their environment. Scholars have also connected an organization's interpretation to its strategic actions, as empirically observed, in relation to environmental changes such as new technologies and customer needs (Chattopadhyay et al., 2001; Fiol, 1990, Nadkarni and Narayanan, 2007; Thomas et al., 1993).

Mainstream research on cognition has traditionally focused on the content issues of strategic beliefs (i.e., what managers believe) and their impact on competition outcomes. For instance, in the transition from analog to digital imaging, a firmly held managerial belief in a razor/blade business model significantly delayed Polaroid's commercialization of a stand-alone 
digital camera and ultimately jeopardized the capability of the company to adapt (Tripsas and Gavetti, 2000). Similar effects have been found in the shift from print to online newspapers (Gilbert, 2006), in pharmaceutical firms' responses to the emergence of biotechnology (Kaplan et al., 2003), and in communication technology firms' responses to fiber optics (Kaplan, 2008b).

All these studies emphasized that mental frames are generally the result of prior history. As senior managers work together, over time, they create a shared understanding of their external environment — or a "dominant logic" that ultimately drives collective decisions and actions (Prahalad and Bettis, 1986). For instance, in the case of Polaroid, the belief in the razor/blade business model was the result of previous experiences under the technology of analog imaging (Tripsas and Gavetti, 2000). Mental frames are often static representations of the business environment and, in changing industries, the difficulty of managers to adapt their history-based beliefs often constrains the scope of their search processes, resulting in organizational inertia and poor performance (Nadkarni and Barr, 2008).

Therefore, a crucial challenge for firms facing environmental discontinuities is managers' ability to assess the accuracy of the beliefs they inherit from their previous experiences by distinguishing those beliefs that still correctly represent the changing competitive landscape from those beliefs that instead represent 'blind spots' (Kaplan, 2011; Walsh, 1995).

\section{Cognitive dynamics and scenario planning}

Whereas most scholars have emphasized the content issues of managerial beliefs and the relationship between such content issues and strategic outcomes, as described above, others have focused on the cognitive dynamics that take place in organizations. Instead of a static representation of cognition in which managers are depicted as constrained by rigid mental 
models, these scholars portrayed cognition as a dynamic process that is influenced—and influences in turn - the process of strategic decision making (Kaplan, 2008b; Laamanen and Wallin, 2009; Szulanski et al., 2004). In particular, a few studies have addressed the impact of scenario planning on managerial beliefs.

Scenario planning — or, alternatively, scenarios — is a predictive approach that aims to envisage alternative futures in the form of different — but internally consistent — configurations of new events and drivers of change (Bradfield et al., 2005; Schwartz 1991). More precisely, scenarios are descriptions of fundamentally different paths presented in a script-like or narrative fashion that tell coherent and credible stories leading to alternative futures (Schoemaker, 1993).

According to scholars and practitioners, the core benefit of scenario planning is not to foresee the future but rather to encourage managers to explore strategic responses beyond the scope of their previous experiences and their established search processes. Scenarios thus enhance organizational flexibility by providing managers with a "head start, as well as a conceptual framework within which to scan, encode, update, and understand the future as it unfolds" (Schoemaker 1993: 200). Eisenhardt (1999) highlights the "frame-breaking ability" of scenarios to "change the decision makers' assumptions about how the world works and compel them to reorganize their mental model of reality" (Wack 1985: 74). In the same vein, de Geus (1988: 73) notes that scenario planning "changes the mental models that decision makers carry in their heads," and Grant (2003: 493) defines scenarios as a "systematic and rational vehicle for learning in changing environments."

De Geus (1997) provides an intriguing explanation for the capability of scenarios to change managerial beliefs. Human brains constantly probe the conditions of the outside world and then immediately consider the actions that they can take, in a constant sequence, on alternative paths 
that yield different futures. Different assumptions about the future can be remembered, often in great detail, exactly like memories of past events because human brains not only construct but also store anticipations about the future, which then become mental models, i.e., "memory of the future". ${ }^{1}$ Without a memory of the future, people would not be able to extract meaningful information from the enormous and random sensory noise to which their brains are continuously exposed in their changing environment:

You personally and your company are being bombarded by an overload of signals from the outside world. [...] The function of the memory of the future is to allow the brain to select those signals that are relevant for you. The test of relevance is your memory of the future. If a signal comes in, it passes through this memory of the future. If it finds a store in an alternative time path, meaning that it is relevant for you, then the signal is translated into data: it becomes information and then information becomes understanding. ${ }^{2}$

The core benefit of scenario planning consists in expanding the mental models of decision makers, i.e., their memory of the future, so that they can better notice and make sense of new events in their external environment:

If you have only one possible alternative path into the future, you see-or hear-very little. This is the real importance of scenario planning. It stretches the time horizon from one or two years to ten or twenty years, and paradoxically, while increasing the time horizon, at the same time, in the present, it increases the power of perception. You hear more signals that are relevant to you. ${ }^{3}$

\section{Scenarios, managerial cognition, and long-term performance}

The use of scenarios as an effective tool for adapting managerial beliefs yields a new

perspective in the research field on cognition. However, although scenarios have been

\footnotetext{
${ }^{1}$ The concept of "memory of the future" was originally introduced by the neuroscientist David Ingvar (1985).

2 de Geus A. 2004. The Living Company - Long Term Thinking in a Changing Society. In the Long Run Conference, Berlin, 18 October. Available in: Burmsteir K, Neef A. (Eds.). 2005. In the Long Run. Oekom: Munich. ${ }^{3}$ Ibid.
} 
extensively praised, we still know very little about their effects on managers' mental models and their impact on strategic investment decisions under uncertainty.

Our thorough literature investigation uncovered only a few empirical studies that examined the relationship between scenario planning and managerial cognition. However, these were experimental studies conducted either with student subjects (Kuhn and Sniezek, 1996; Meissner and Wulf, 2013; Schoemaker, 1993) or field experts (Phadnis et al., 2015); none of these studies addressed the case of business managers who have concretely built and used scenarios to make strategic investment decisions in a rapidly changing environment.

Furthermore, these previous works were based on one-time use of scenarios rather than continual use. Overall, there are no longitudinal studies exploring the ability of scenarios to influence the evolution of the beliefs that managers have developed through their prior history and to enhance their cognitive processes of attention and interpretation. Scholars have acknowledged this gap in the literature (Wilkinson, 2009; Phadnis et al., 2015), and Schoemaker (2004: 288), one of the most cited authors in the field of scenario planning, has stated that evidence on the effectiveness of scenarios is anecdotal.

This gap in the literature reveals a timely opportunity to develop a more complete and theoretically rich understanding of the relationship between scenario planning and cognitive dynamics. In this paper, we seek to seize this opportunity. We extend current theory and create new insights by exploring how scenarios affect managerial cognition and contribute to strategic investment decisions in a turbulent environment.

Given the critical influence of top executives on strategic investments and the previous work of mainstream scholars in the field of managerial cognition and organizational performance, we focus on cognition at the level of the senior management team (Barr et al., 
1992; Laamanen and Wallin, 2009; Tripsas and Gavetti, 2000).

Our central contribution concerns cognitive dynamics in corporate organizations (Kaplan, 2011). We find that managers can use scenarios to effectively adapt their mental models to a changing environment (Phadnis et al., 2015). We show that even if scenarios are unlikely to predict all future events accurately, they can still anticipate the future sources of competitive advantage and shape managers' beliefs about these sources. Scenarios can thus lead to the rise of a new dominant logic that ultimately enhances decision makers' capability to respond to external events, even if these events are not expected.

\section{Methods and Data}

Given the gap in the literature, the open-ended nature of our question and its strength for theory building, we adopted the case study methodology (Eisenhardt, 1989; Miles and Huberman, 1994). We used a single-case and longitudinal research design because it allows one to richly describe the existence of a phenomenon and the conditions under which this phenomenon might occur (Eisenhardt and Graebner, 2007). This research follows in the tradition of in-depth case studies to investigate managerial beliefs and their role in strategic responses to environmental changes.

\section{Research setting}

The research setting is a major multinational company that used scenarios to cope with the growing turbulence of its industry. Specifically, we studied the ventures of Royal Dutch Shell in the Russian energy market from the mid-1990s to 2016. 
After the collapse of the Soviet Union in 1991, under the leadership of President Yeltsin, the Russian government encouraged the entry of foreign investors to exploit its enormous reserves of oil and natural gas. Foreign partners were needed to provide technical, logistical and commercial capabilities, and major energy companies were attracted by the opportunity to expand their exploration and production activities.

In the mid-1990s, and again in more detail in 1999, the Russian Parliament enacted new laws to promote ad hoc commercial contracts between the Russian government and foreign investors. These contracts, namely, production sharing agreements (PSAs), involved selected projects and offered very favorable conditions for foreign partners, such as financial arrangements outside the country's normal tax and licensing regimes.

In April 1994, Shell established the Sakhalin Energy Investment Company (SEIC, hereafter, Sakhalin Energy) with Marathon, McDermott, Mitsui and Mitsubishi. (Subsequently, between 1994 and 2000, Shell gradually bought the shares of Marathon and McDermott and increased its stake in Sakhalin Energy from 20\% to 55\%, with Mitsui and Mitsubishi holding $20 \%$ and 25\% stakes, respectively.) In June 1994, Shell was then the first energy major to sign a PSA with the Yeltsin government, which granted the company a license to develop the Sakhalin II project, i.e., two oil and gas fields off the coast of northern part of the island of Sakhalin. The first, i.e., Piltun-Astokhskoe, was mainly an oil field, whereas the second, i.e., Lunskoe, was primarily a gas field with associated condensates. At the time, they represented together the single largest integrated oil and gas field in the world, with potential recoverable resources reaching 1.2 billion barrels of oil and 600 billion cubic meters of natural gas.

Shell structured the investment project into two main phases. The first, which involved the development of the Piltun-Astokhskoe oil field, began in 1996. The second, which involved the 
development of the Lunskoe gas field, was delayed until the mid-2000s.

With the rise of President Vladimir Putin in 2000, however, the Russian institutional environment and the energy sector in particular experienced huge discontinuities. The attitude of the new government toward foreign investors turned out to be less favorable as it gradually sought to establish its own control of local companies and oil and gas resources.

To support its strategic investment decisions under such extreme conditions of uncertainty, Shell engaged in extensive scenario planning. Since the early 1990s, scenarios helped top decision makers explore external changes and their implications for project execution, especially regarding the next development of Sakhalin II after the election of President Putin. Shell's venture in Russia thus provides a compelling research setting for investigating our research question regarding the relationships among scenario planning, managerial cognition, and competition outcomes in a turbulent environment.

\section{Data collection}

The focal period of interest for our longitudinal study is from 1994 to 2016 . The study period starts in 1994, when Shell entered the Russian energy market, and ends in 2016, when the company laid the foundations for the further expansion of its operations in the country. In particular, we examine the co-evolution of scenarios and beliefs after 2000, when President Putin was elected and Shell had to decide whether to invest a massive amount of financial resources in the development of the Lunskoe gas field. Data collection started in 2002 and covered the following topics: i) the methodological and organizational framework of scenario planning at Shell; ii) the managerial beliefs about the future evolution of the Russian institutional environment and energy industry; iii) the major changes and events that occurred in Russia; iv) 
the strategic responses of Shell to these events; and v) the performance of Shell in Russia (oil and gas production, exports, and profits).

The data collection process was iterative and relied on two primary data sources, namely, archives and interviews. We first gathered extensive archival data from both internal and external sources. The internal sources included publications about scenarios, annual reports, financial analyst reports, press releases, internal reports, presentations by the firm's executives at public conferences, and technical papers. The external sources included prior studies of Shell's history and the development of its scenario methodology, business press releases and media articles about the operations of Shell and other global energy majors in Russia selected via ABI/Inform, complemented with analyst reports and books. Business press and trade press publications included, among others, The Economist and the Financial Times, as well as press agencies such as Reuters. We used these archival data to develop the chronological case history of Shell and organized the data by year, and we detailed relevant events and decisions that affected the operations of the company in the country.

Our second main data source was interviews with internal and external informants. Interviews were semi-structured in that they were open-ended and based on a set of common questions regarding scenarios and emerging strategic beliefs (e.g., expectations, forecasts, assumptions) about the Russian institutional environment and energy market. Internal informants included top managers and business executives, who were selected according to their tenure in the firm, their direct involvement in the building and use of scenarios, and their involvement in the operations of the company in Russia. In particular, we interviewed the heads of scenario planning, scenario practitioners, corporate planners, economists, and managing directors. External informants included industry experts and consultants selected according to their direct 
knowledge of Shell and their reputation. (The sensitivity of issues pertaining to the relationship between Shell and the Russian government partially constrained the information we could gain from interviews. However, the interviews with company managers were still extremely helpful to collect data about the general contents of the scenarios, the process through which they were formulated, and their impact on strategic investment decisions).

Altogether, we conducted 26 interviews. The interviews generally lasted between one and two hours and were conducted between 2002 and 2010.

\section{Data analysis}

The data analysis used traditional approaches for case study research (Bettis et al., 2015; Eisenhardt et al., 2016; Locke, 2001; Yin, 2003). Data analysis and data collection proceeded in a highly iterative day, as new data were used to test the robustness of our emerging interpretations about the mutual influences of scenarios and cognition.

Our research question (i.e., how do scenarios affect managerial cognition and strategic investment decisions in a turbulent environment?) guided the prioritization of the analytical process. In the early stage, we carefully examined our informants' data on scenario planning activities, aiming at producing a rich description of emerging managerial beliefs and their role in strategic investment decisions. According to prescriptions for grounded-theory building, data were content analyzed, searching for emerging codes and categories (Charmaz, 2006; Locke, 2001; Strauss and Corbin, 1990). Codes and categories were labeled in terms that were close to the words used by Shell's executives, especially our informants, to express their beliefs about the likely evolution of the Russian institutional environment and the local energy market. These beliefs - and their relationship with the scenarios — clearly resulted from our data in the form of 
forward-looking statements such as “our scenarios indicate," "our scenarios anticipate," "according to our scenarios", "we believe," "we assume," and "we expect."

The coding process was highly iterative. In a first round of data analysis, codes were used to highlight basic beliefs about future changes in customers, markets, technologies and competitors. Subsequent rounds of data analysis helped us to categorize basic codes and group them into macro codes illustrating the beliefs of Shell's managers about future sources of success in the Russian and Asia-Pacific energy business. These beliefs are described in the next sections of the paper and summed in Figure 1.

The coding process evolved through constant comparison and occurred on two levels: within each interview and official document, which helped identify emerging beliefs; and across interviews and official documents, which helped identify the recurrence and strength of these beliefs. Following past research on cognition and capabilities (e.g., Tripsas and Gavetti, 2000), we checked the consistency between managerial assumptions about the future and major investment decisions (e.g., oil and gas fields and assets). We also tracked the time of these decisions and compared them with those of the other energy majors that were operating in Russia. Furthermore, following past research on scenario planning (e.g., Phadnis et al., 2015), we contrasted the assumptions that stemmed from scenarios with the prior individual and organizational experiences of Shell's managers. We thus checked whether these assumptions were consistent with previous history or represented discontinuity instead. These different levels of investigation helped us to assess the confidence of Shell's managers in their scenarios — and related beliefs — and their ultimate role in directing search processes in the turbulent Russian market.

In each step of collecting and analyzing data, we used tables and memos to summarize our 
main findings and early interpretations and to track and develop our emerging insights. We then followed an iterative process of cycling among the data, emerging theory, and the literature to refine our central constructs and theoretical propositions, relate them to existing theories, and clarify our contributions.

\section{Scenario Planning at Shell: Historical Evolution (1972 - 1990) and Entry into Russia (1991 - 2000)}

When the Soviet Union collapsed in 1991, Shell already had longstanding experience with scenario planning (Cornelius et al., 2005; Davis 2002). Following its initial introduction in the late 1960s, a scenario suggesting that disruptions of the oil supply could result in a sharp rise in prices was built by Shell's managers in 1972. The company thus anticipated the crisis that took place just one year later when, in October 1973, Arab oil-producing countries imposed an oil embargo on western governments as a consequence of the US's support for Israel in the Yom Kippur war. In a few weeks, the price of crude oil increased from $\$ 2.5$ a barrel to $\$ 11$, causing a slump in the stock market in western countries, a contraction of economic activities and a rise in unemployment (Yergin, 1990). Later on, the growing nationalism of some oil-producing countries in Middle East led to the rise of local companies, with the expropriation of oil fields from western energy majors.

However, thanks to its scenarios, Shell was prepared for the crisis and the company could recover more quickly than competitors. In 1972, Shell had already begun to diversify in downstream oil activities (marketing and distribution) and in gas production through the opening of a major plant in Brunei. 
After the oil crisis, scenarios were adopted widely throughout the company and gradually evolved in terms of both scope and process. The initial focus of the early 1970s on the key variables of energy demand and oil prices widened to include events in the economic, political, social and environmental (ecological) landscapes. Scenario planning became a systematic analytical process that involved all the top managers of the company, above all, the CEO and the other executive directors. This process consisted of (i) listing predetermined elements and trends in the global energy market; (ii) identifying drivers of change in the external environment that could affect the competitive position of the company; (iii) exploring the likely patterns of evolution of drivers of change; (iv) building the scenarios' plots and narratives; (v) analyzing the industry and market structure that would prevail in each scenario; (vi) identifying the rising sources of competitive advantage; and (vii) generating and evaluating options for strategic action.

As a result, in the early 1990s, scenarios already encompassed three different levels of analysis, which a senior manager described as follows:

First of all, we develop our 'global scenarios' exploring forces in the global macroenvironment encompassing politics, economy, society, ecology, technology, and demographics. [...] Based upon global scenarios, we build 'focused' scenarios' concerning each business sector of the energy industry and each geographic area in which we operate. [...]. Finally, 'project scenarios' investigate specific investment projects by processing more detailed information on competitors, profitability, technical and managerial risk.

Shell's "global scenarios" were regularly built every three years and usually covered a time horizon of 20 years. The global scenarios that were released in 1992 focused on three drivers of change: globalization, liberalization, and technology. These scenarios described two alternative futures: in the first, "New Frontiers", the forces of economic and political liberalization were largely embraced throughout the world; in the second, "Barricades", the same forces were 
eventually resisted. By 1995, it seemed clear that the forces of globalization and liberalization were established and, building on the previous "New Frontiers", the new "Just Do It!" and "Da Wo" global scenarios were released. The first stressed individualism and libertarianism, whereas the second emphasized cohesion and the adoption of a communitarian approach by governments in Europe and Asia. The 1998 global scenarios expanded the previous "Just Do It!" and identified again two alternative futures. The first, "The New Game", stressed the challenge of global problems and the development of new international institutions and rules for the health of the global economy, whereas the second, "People Power", emphasized the flowering of diversity among citizens of different countries and the rapid obsolescence of institutions.

Global scenarios represented the general framework through which more detailed "focused scenarios" were built to address every business segment and country in which the company operated. The focused scenarios were also multiple scenarios (generally 2 or 3 ) that combined macro-drivers of change in the global energy business with more specific market issues regarding the strategic behavior of Shell's competitors, suppliers, and customers. Precisely, while the global scenarios set the macroeconomic framework within the global energy business, focused scenarios narrowed the strategic funnel by analyzing demand and supply trends in individual energy markets. Finally, the "project scenarios" explored the likely impact of the global and focused scenarios on specific investment projects by gathering and processing more detailed information about competitors, oil prices, and profitability.

In particular, in the early 1990s, country scenarios addressed the likely evolution of the Russian political and institutional environment and the likely attitude of the Yeltsin Government towards foreign investors. These scenarios foresaw the opening of Russia to foreign investors as a huge opportunity to expand Shell's reserves and operations in the Asia-Pacific region, where 
the demand for energy was expected to grow at a very fast rate. A senior manager explained the following:

At that time [early 1990s], our scenarios increased our confidence that, under the leadership of President Yeltsin, the dismantling of the Soviet Union and the liberalization of the Russian market were irreversible trends.

Project scenarios then further helped Shell's managers to evaluate different investment options in the country by addressing the reserves (proven and potential) of the oil and gas target fields; the natural, morphological, and weather conditions affecting the exploration and production of oil and gas; and the methods and technologies for transporting them. Project scenarios also considered the economic growth in target export markets, such as Japan, South Korea, and China; the possible customers and partners; and the other major energy companies that could enter the Russian market and establish rival projects aimed at the same export markets. These scenarios led Shell to establish Sakhalin Energy in 1994 and begin developing the PiltunAstokhskoe oil field project in 1996.

\section{Shell in Russia (2000 - 2016): Scenarios, Managerial Beliefs, and Investment}

\section{Decisions}

In the early 2000s, scenario planning remained a systematic process through which Shell's managers met and shared their insights about forthcoming changes. The company largely applied the deductive approach to scenario planning (Schwartz 1991), through which Shell's managers reflected on their prior individual, organizational, and industry experiences and framed the lessons learnt from these experiences around opposite—but internally coherent—hypotheses about the future. These hypotheses were summarized in the global, country, and project scenarios and articulated the divergent opinions of managers regarding the likely evolution of the global 
energy business and the Russian institutional environment.

In particular, in 2002, Shell's managers released the new "Business Class" and "Prism" global scenarios. The first focused on the geography of the whole earth as an interconnected system: it explored the impact of human activities on the global natural system and assumed that national governments would work together towards greater economic integration and environmental sustainability. This scenario emphasized the rising role of gas as cleaner, more sustainable source of energy that could protect the interests of future generations. In contrast, the second scenario questioned the monochromatic world of global integration and explored the rise of a new regionalism leading to the pursuit of idiosyncratic national interests. This scenario emphasized the persistence of oil as the main global energy source. Similarly, among the Russian country scenarios that were built at that time, one envisaged continuity between the policy of the new Putin administration and that of the previous Yeltsin government, with a friendly attitude towards foreign investors. On the contrary, another scenario envisaged a growing nationalism of the new government.

Overall, in the early 2000s global and country scenarios articulated the following alternative hypotheses - i.e., strategic beliefs — of Shell's managers about the future energy industry and the Russian institutional environment: i) gas (in particular LNG, liquefied natural gas) as the primary energy source, as opposed to oil; ii) gas transportation infrastructure (i.e., pipelines and LNG plants) as the main priority, as opposed to oil-related midstream and downstream assets; and iii) growing interventionism of the new Putin government, as opposed to friendly support.

The strategic belief about the primary role of oil and the related infrastructure clearly stemmed from the mainstream history of Shell and the whole energy industry. The opposite 
belief about the rising relevance of gas was also consistent with some previous investments of the company (e.g., the opening of its first LNG plant in Brunei in 1972); however, this belief clearly represented a discontinuity from the mainstream history of oil majors like Shell.

Similarly, the belief about the growing nationalism of the new Putin government reflected the previous experiential lessons learned by oil majors in producing countries in the Middle East and West Africa. In contrast, the opposite belief in friendly support from the Putin administration stemmed from the mainstream history of the company in Russia under the previous Yeltsin government.

On the one hand, scenarios had a strong influence on Shell's investment decisions. On the other hand, performance feedback from those same decisions and changes in the Russian energy market contributed to the evolution of scenarios and managerial beliefs through a continuous process that lasted for more than a decade. Performance feedback and market changes contributed to reinforcing either the first or the second of the above assumptions about the future, which were then investigated further in the next scenarios and eventually emerged as the dominant beliefs of Shell's managers.

We frame the description of this co-evolution process around four key periods regarding the company's venture in Russia: 1) from 2000, when President Putin was elected, to 2003, when Shell began its massive investments in the second phase of Sakhalin II; 2) from 2003 to 2005, when Shell made an initial agreement for a partnership with Gazprom; 3) from 2005 to 2006, when Shell finalized the entry of Gazprom in the Sakhalin II project; and 4) from 2007 to 2016, when Shell and Gazprom laid the foundations for the future expansion of Sakhalin II.

Scenarios, beliefs, market changes, and investment decisions: 2000-May 2003

Oil vs. gas as the primary energy source. Whereas the "Prism" scenario emphasized the 
continuing of a "long oil game" and depicted a world in which oil would remain "the dominant global fuel for another two decades", the "Business Class" scenario envisaged an alternative world in which gas would gradually prevail against oil and become the primary global energy source:

Gas is 'the great game' in energy because consumers want it for health and environmental reasons, businesses want it as a source of new wealth. ${ }^{4}$

Oil vs. gas (LNG) infrastructure. The "Prism" and the "Business Class" scenarios further explored the role in the future energy industry of the oil- vs. the gas-enabling infrastructure. In particular, the "Business class" scenario assumed that LNG technology would be a key enabler of the expansion of the gas market. (LNG is a non-toxic liquid that can be transported and stored more easily than natural gas because it occupies as much as 600 times less space, thus considerably increasing the choices of both producers and consumers regarding where they can sell or buy gas.) LNG required ad hoc pipelines for transporting the gas and ad hoc terminals for liquefying and then shipping it. The "Business Class" scenario made the assumption that such LNG-enabling infrastructure would become a major source of competitive advantage in the changing energy market:

Like the boom in the railway infrastructure of the nineteenth century that transformed the world of manufacturing, the growth of the gas infrastructure in the early years of the twenty-first century transforms the energy landscapes.

If gas is the backbone of the future energy system, two major strategic bets face gas suppliers: developing major cross-border pipelines to connect remote gas fields to customers, for example, in Asia; securing low cost or strategically placed gas resources [...].

\footnotetext{
${ }^{4}$ Shell Global Scenarios to 2020: "People and Connections", Shell International Limited, 2002.
} 
In spite of the growing popularity of gas, selling energy units is not the largest game. The big prizes go to: companies that acquire strategic resources or that place large bets and create the enabling gas infrastructure, particularly large cross-border pipelines and strategically placed LNG terminals. ${ }^{5}$

Friendly attitudes vs. interventionism by the new Russian government. After the election of President Putin in 2000, Shell's country scenarios focused on the evolution of the Russian institutional environment, as the new administration quickly exhibited a different attitude towards foreign investors from the previous Yeltsin regime, and Shell's managers wondered what the implications would be. When, in 2002, a number of new laws about PSAs were proposed, Shell's top executive Steve McVeigh noted the following:

The Anti-Monopoly Law gives the government the right to force third-party allocation into oil and gas facilities such as pipelines at government-determined tariffs vs. arm-length commercial arrangements such as [that] provided in our PSA. The Gas Supply Law allows the government to force a private gas pipeline company to sell gas to third parties at government-determined prices. The current Draft Trunk Pipeline Law under consideration by the Duma would bar foreign ownership of oil and gas export pipelines. And finally, passage of the PSA chapter of the tax code is necessary to clarify and anchor the means for reimbursement of VAT to the investor as provided in the PSA. These laws must be amended or passed to guarantee our PSA rights. ${ }^{6}$

Shell's managers thus investigated further the likely scenario in which the Putin administration would increase its ambition to control local energy sources by assuming that this ambition could become a serious barrier to the construction of any pipelines or LNG plants by foreign investors.

A senior manager explained as follows:

Our scenarios focused on these questions: will Russia still be a good environment in which to do business? Who will be in charge in the next 20 years? What will be the attitude of the local authorities towards foreign investors? After the fall of Yeltsin and the rise of Putin, we considered significant changes in the Russian institutional environment and the energy sector.

\footnotetext{
${ }^{5}$ Ibid.

${ }^{6}$ McVeigh S. 2002. Sakhalin 2 - on Track to Phase II. Sakhalin Oil \& Gas Conference, London, 18 November.
} 
Proximity is clearly the dominant factor in marketing $L N G$ from Russia to customers in Japan, Korea, and North America, but getting access to local gas fields is not enough: we need to liquefy and transport gas to target customers. The key issue is the development of the $L N G$ plants and the pipelines required for exporting gas. What if new laws are enacted and applied to our project?

Another senior manager commented as follows:

For major export markets in the Asia-Pacific region, Russia has abundant sources of gas supply which lie within a radius of some thousand kilometers. The joint development of pipelines and strategically located $L N G$ plants can increase the accessibility to these markets. Our scenarios indicate that pipeline and plant development of such a scale is feasible but costly and politically complex: we need the full support and collaboration of the Russian government.

The strategic assumptions about the growing ambition of the Putin administration and the relevance of gas had a clear impact on the strategic actions of Shell's top executives. First, in early 2003, they requested an official letter from the Russian government providing assurance that it intended to honor the PSA governing Sakhalin II. Only after they received this letter, in May 2003, did they begin the second phase of the project. Shell's managers decided to build a gas pipeline crossing the whole island of Sakhalin from north to south and an LNG plant and export terminal at the southern end of the island. The pipelines had to go through more than 1,000 rivers, several nature reserves, active seismic faults, and possible unexploded war ordnances dating back 50 years. The second phase of Sakhalin II, i.e., the development of the Lunskoe gas fields and the building of the LNG-enabling infrastructure, represented the single largest project in Shell's history, with investments expected to reach $\$ 10$ billion. Shell scheduled the completion of the infrastructure and the beginning of the gas exports by the end of 2008 .

Scenarios, beliefs, market changes, and investment decisions: May 2003-June 2005 
After it started the second phase of Sakhalin II, Shell quickly secured customers for most of the gas that it planned to produce and export. In April 2005, Malcolm Brinded, group managing director and CEO of Shell Gas and Power, noted that

About 70 per cent of the project's LNG has now [April 2005] been sold on long-term contracts and I think that strongly underlines how attractive Russian gas is to the market. ${ }^{7}$

This positive market feedback and the new scenarios that Shell built in the mid 2000s concurred to strengthen the managerial belief about the "vital role of gas in a sustainable energy future", as illustrated by Malcolm Brinded:

Our scenarios indicate very firm growth in gas. Oil will continue to be important through to mid-century, but gas could overtake oil as the global number one fuel of choice by 2025. [...]

What are the factors that are really redefining the 'role' of gas in the energy future? First, environmental benefits are an increasing driver for rising gas usage. At the local air quality level, as a very clean burning fuel - and at the global level, because of the significant CO2 emissions advantages, versus coal and oil. [...] Second, because, for the first time, conditions for LNG imports are right in all major gas import markets of the world-North America, Asia and Europe. [...]

Gas has a long-term and vital role in a sustainable energy future: one that delivers economic and environmental performance as it benefits societies. Our children should understand this message. Gas will not be resource constrained for the foreseeable future. ${ }^{8}$

Shell's scenarios also reinforced the managerial beliefs about the strategic relevance of LNG and

the gas transportation infrastructure in the future energy market:

Mobility has always been the constraint on growth of the global gas trade, but the impact is reducing, and LNG is the key driver. Long-distance delivery costs in LNG shipping have been cut by more than half since 1990. This trend opens up global gas resources to all distant markets. We can expect the trend to continue, with further advances in technology and also economies of scale, as seen from various plans for very large LNG trains and

\footnotetext{
${ }^{7}$ Brinded M. 2005. The vital importance of Russia in the world's energy future. Russian Economic Forum, London, 11 April (retrieved from Shell media center: www.shell.com [18 November 2005]).

${ }^{8}$ Brinded, M. 2004. The Vital role of gas in a sustainable energy future. CERA Conference, Houston, 11 February (retrieved from Shell media center: www.shell.com [20 January 2005]).
} 
larger LNG ships. As a result, gas is being unlocked from locations more and more remote from the markets they serve. ${ }^{9}$

Shell energy scenarios indicate that [....] global gas growth between now [November 2003] and 2030 will be substantial. And we can see LNG growing especially fast-by a factor of 5 by 2030. We also know that LNG will be travelling over greater distances. The major gas reserves are far from the major markets. So LNG trade will connect gas markets that were previously regional 'islands.'. ${ }^{10}$

Contextually, after Shell started the second phase of Sakhalin II, some major events occurred in the Russian institutional environment that contributed to strengthening the belief about the growing ambition of the Putin administration and its interventionism in the local energy industry. By the end of 2003, the Russian government gained full control of Gazprom, a local energy company involved in the exploration, production, transportation, and marketing of gas, and granted Gazprom itself a de facto monopoly over the gas exports from the country. Furthermore, the government greatly reduced the number of oil and gas fields eligible for development under PSAs.

In October 2003, the Russian government also arrested Mikhail Khodorkovskii on charges of tax fraud. Khodorkovskii, who had built his success in the Yeltsin era as the owner of Yukos, Russia's second largest oil company, was widely known as one of the richest men in the country and one of the most vocal opponents of the administration of President Putin. Khodorkovskii was sentenced to nine years in prison, and a few months later, his oil company was dismantled and bought out by a few state-controlled companies (among which Gazprom).

In March 2004, President Putin again won the election, with $72 \%$ of votes. In the same

\footnotetext{
${ }^{9}$ Brinded, M. 2004. The Vital role of gas in a sustainable energy future. CERA Conference, Houston, 11 February (retrieved from Shell media center: www.shell.com [20 January 2005]).

${ }^{10}$ Brinded, M. 2003. The changing global gas market. Oil and Money Conference, London, 5 November (retrieved from Shell media center: www.shell.com [20 January 2005]).
} 
year, tenders awarded to ExxonMobil and Chevron for developing new oil and gas fields in the island of Sakhalin, under the forthcoming Sakhalin III project, were annulled by the government because of irregularities in the auction documentation. (A few months later, the licenses for the development of Sakhalin III were given to Gazprom.) In the same year, the Russian State Audit Department investigated the Sakhalin II project on charges of financial damages, and in 2005, the Minister of Natural Resources Yury Trutnev announced that neither foreign companies nor domestic companies managed from abroad would be allowed to bid for the future rights to develop Russian oil and gas fields.

Consistent with such events and the belief in the growing interventionism of the Putin administration, Shell's managers attempted to secure the support of the latter for the development of Sakhalin II. After protracted negotiations, in June 2005, Shell and Gazprom signed a memorandum of understanding to swap shares in two oil and gas projects, namely, Sakhalin II and Zapolyarnoye-Neokom, from which Gazprom would receive a 25\%-plus-oneshare stake in the Shell-led Sakhalin II consortium, with Shell remaining as the field operator, in return for 50\% of Gazprom's share in Zapolyarnoye-Neokom. The words that Shell CEO Jeroen van der Veer used to comment on the swap agreement are particularly indicative of the purpose to stabilize the operations of the company:

"We welcome Gazprom as a great Russian partner in the Sakhalin II project and are confident Gazprom will make significant contributions towards maximizing the long-term value of the project. [...] Today strengthens the good relationship between Shell and Gazprom." 11

At the time of the swap agreement, Malcolm Brinded also commented on the strategic need to

\footnotetext{
${ }^{11}$ Gazprom and Shell sign memorandum of understanding to swap shares in Zapolyarnoye-Neokomian and Sakhalin -II projects. 2005. Retrieved from Shell Media Center: www.shell.com [7 July 2005].
} 
strengthen the relationship between Shell and the Putin administration:

"Over recent times, there's been a great deal of discussion about the investment climate in Russia. From Shell's perspective, the experience from our specific projects has been positive. The massive investment in the Sakhalin II project was only secured with support from government."12

Scenarios, beliefs, market changes, and investment decisions: June 2005-

\section{December 2006}

Soon after it signed the share-swap agreement with Gazprom, Shell announced that the expected costs of the second phase of Sakhalin II were double the original estimates, growing to $\$ 20$ billion. The main reasons for the cost overrun were the large increases in the prices of local labor and materials (e.g., the steel used for the pipelines), weather-related delays, and modifications to the route of the project's underwater pipelines to both minimize risk from possible earthquakes and protect the salmon breeding areas and the region's western grey whales.

Cost overruns exacerbated the relationship with the Russian government and slowed down the negotiations with Gazprom. Gazprom's executives were displeased with not having been informed about these increased costs before agreeing to the asset swap deal and offered a significantly smaller stake in the Zapolyarnoye-Neokom field, as they argued that the value of Sakhalin II assets had been diluted. By the summer of 2006, the deal with Gazprom was still stalled, although the development of Sakhalin II was proceeding quickly. Meanwhile, environmentalists raised concerns about the effects of the transportation infrastructure on the

\footnotetext{
${ }^{12}$ Brinded, M. 2005. The vital importance of Russia in the world's energy future. Russian Economic Forum, London, 11 April (retrieved from Shell media centre: www.shell.com [18 November 2005]).
} 
island's ecosystem. These concerns reached the Russian government, which ordered an inspection into alleged violations of both the ecological legislation and Shell's project specifications. The inspectors found what they considered to be several violations, and in September 2006, the Russian Ministry of Natural Resources suspended the environmental licenses that were mandatory for the completion of the pipelines. The Russian government threatened to revoke the licenses permanently and to prosecute Shell and its partners for criminal action, as it estimated the project consortium's liability for environmental damages to be several billion dollars.

The response of Shell's managers was bold, quick, and consistent with the strengthening belief in the growing ambition of the Russian government and the strategic relevance of the gasenabling infrastructure. In December 2006, the company agreed on a new deal that installed Gazprom as the leading shareholder and (starting from 2009) as the new operator of the project consortium. Gazprom purchased a 50\%-plus-one-share stake from the project partners for a total sum of $\$ 7.45$ billion; Shell, similar to its original partners in Sakhalin Energy, cut its initial stake by half and retained a $27.5 \%$ stake and did not gain any shares in the Zapolyarnoye-Neokom field. However, through the new deal, the company tried to finally secure the support of the Putin administration and to expedite the completion of the gas pipelines and the LNG plant. Malcolm Brinded commented

Gazprom's entry into the Sakhalin Project is warmly welcomed. Combined with the government acceptance of the Environmental Action Plan, this is another important step for Sakhalin II. ${ }^{13}$

${ }^{13}$ Gazprom Enters Sakhalin II Project: http://www.prnewswire.com/news-releases/gazprom-enters-sakhalinii-project-58568837.html [18 April 2007]. The Environmental Action Plan was the document illustrating Shell's measures to protect the natural ecosystem of Sakhalin. 
Scenarios, beliefs, market changes, and investment decisions: 2007-2016

After Shell signed the new deal with Gazprom, the allegations of ecological damages were withdrawn, the licenses of Sakhalin Energy were reinstated, and the LNG plant and pipelines were successfully completed. Gas exports commenced in 2009; at the official launch of the LNG plant, Ian Craig, Shell's top executive and Sakhalin Energy's CEO, emphasized:

Sakhalin has established itself on the global energy map. We thank shareholders of Sakhalin Energy, the Government of the Russian Federation and the Sakhalin Oblast Administration for their continuous support and cooperation in delivering the ambitious and challenging Sakhalin II project. After reaching its full capacity, the Sakhalin II project will ensure around 5 per cent of the global LNG production and contribute significantly to strengthening the global energy security. ${ }^{14}$

The project reached full capacity in 2010, when Gazprom, Shell and their partners exported nearly 10 million tons of LNG, mostly to Japan and South Korea, and received revenues in excess of $\$ 6$ billion and profits of more than $\$ 2$ billion. In 2011, LNG exports from Sakhalin II to Japan increased to cover the country's extra needs from the Fukushima disaster and the loss of several nuclear facilities. The project consortium increased its revenue to $\$ 8.6$ billion and its net profit to $\$ 4$ billion. The amount of gas production and exports increased slightly in subsequent years, peaking in 2014 at 10.8 million tons of LNG (with $\$ 3.1$ billion in net profit).

Based on this successful collaboration, in June 2015, Shell and Gazprom signed an agreement to expand Sakhalin II by building a third train (i.e., processing facility) in their LNG plant in southern Sakhalin. The new train was expected to increase the current capacity by half. Contextually, in August 2015, Shell agreed to swap a stake in one of its international energy assets for part of Gazprom's stake in the Sakhalin III project: the latter one was expected to

\footnotetext{
${ }^{14}$ Gazprom. 2009. First Russian LNG plant launched in Sakhalin. 18 February: http://www.gazprom.com/press/news/2009/february/article64569/
} 
contribute to supplying the additional LNG train of Sakhalin II. ${ }^{15}$ After the completion of project feasibility studies, in March 2017, Gazprom announced a plan to launch the third LNG production train in 2023 .

Notably, throughout the 2010s, the success of Sakhalin II has spurred Shell's top executives to expand not only Sakhalin II itself but also the overall gas operations of the company and the LNG business in particular. Among others, Shell acquired the BG Group in 2015 for $\$ 50$ billion.

\section{A Framework for Scenarios, Cognition, and Investment Decisions}

Figure 1 summarizes our findings from the case study of Shell regarding the co-evolution of managerial beliefs, market changes, and investment decisions in the turbulent Russian market.

'Insert Figure 1 about here'

Our findings show that Shell's scenarios failed to predict some major events that occurred in Russia in the early and mid-2000s. In particular, the scenarios did not anticipate the acquisition of Gazprom by the Russian government and the granting of the exclusive right to export gas to this company, the arrest of Khodorkovskii and the dismantling of Yukos, the cost overruns of Sakhalin II, the allegations of violating environmental laws and the subsequent suspension of pipeline-related licenses, and the threats of court proceedings and definitive halt of the pipelines. However, Shell's eventual success in gas production, exports and profits demonstrates that its

\footnotetext{
15 The entry of Shell in the Sakhalin 3 project was later suspended in 2015 because of the Ukrainian crisis and the US sanctions against Russia.
} 
scenarios — and, more specifically, the dominant beliefs that these scenarios helped to informenabled the company to adapt to these unpredicted events in a timely and effective manner. Shell was the first and only foreign company to produce and export gas from Russia for almost a decade, between 2009 and $2017 .^{16}$

Our findings thus suggest an emerging conceptual framework for the relationship among scenarios, cognitive processes of attention and interpretation, and strategic decision making in uncertain environments.

\section{Scenarios, managerial beliefs, and strategic investment decisions}

Scenarios and cognitive dynamics. Scenario planning allowed Shell's managers to frame the wide and heterogeneous array of knowledge they cumulated through their previous experiences into opposite assumptions about the future. Specifically, through their deductive methodological approach, scenarios guided managers in systematically making alternative hypotheses for the likely evolution of the global energy business, the Russian market, and the Sakhalin II project, with each hypothesis reflecting some of the different lessons Shell managers had learned from prior history. These alternative hypotheses regarded the prominent role of oil vs. gas; the main priority of the oil- vs. the gas-enabling infrastructure; and the friendly support vs. the growing interventionism of the new Putin government. On the one hand, some assumptions (i.e., the prominent role of oil and the related infrastructure; friendly support by the Putin administration) represented a continuity with the mainstream history of Shell in the energy

\footnotetext{
${ }^{16}$ In December 2017, the Yamal LNG project in northern Russia made the first shipment of LNG: Total (which owns a 20\% stake in the project) thus became the second (and only) western company after Shell to export gas from Russia.
} 
industry and Russia. On the other hand, the opposite assumptions (i.e., the prominent role of gas and the related infrastructure; the growing interventionism of the Putin government) represented a clear discontinuity from mainstream history. As long as new events occurred in the Russia and the global energy market throughout the 2000s, these events gradually contributed to reinforcing the latter discontinuous beliefs, which gradually rose as the ultimate dominant collective frames of Shell's managers.

The beliefs about gas and the LNG-enabling infrastructure are very helpful to appreciate the cognitive dynamics that were induced by the scenarios. For almost a century, the mainstream business of the energy industry had been in oil: decision makers had been focusing on a definitive question, which, in the early 2000s, a former Shell manager still explained to us as follows: "What will be the price of oil?" At that time, given the influence of the company's prior history, Shell's managers likely believed that future success in the Asia-Pacific region would still come from the expansion of its oil reserves and operations in Russia. Indeed, this belief was articulated in the "Prism" scenario and was consistent with the first phase of the Sakhalin II project, i.e., the development of the Piltun-Astokhskoe oil field in the late 1990s. (Remarkably, this belief was also consistent with the investment decisions of many other majors that attempted to enter the Russian market in the 2000s, as we illustrate later on this section). However, the "Business Class" scenario articulated the alternative, disruptive managerial belief that gasinstead of oil—would become the prominent source of energy and that LNG-enabling infrastructure — instead of oil-related midstream and downstream assets—would be a major source of competitive advantage. This scenario enabled such disruptive beliefs to emerge and, following the growing demand for LNG from customers in Japan and South Korea, contributed to making these beliefs the new dominant logic of the company. 
Similarly, at the time of the first election of President Putin in 2000, given the influence of the company's prior history in Russia, Shell's managers likely believed that the new government would keep supporting foreign investors. However, the scenarios articulated the disruptive belief that the ambition of the Putin administration would grow and become a major barrier to the completion of the LNG-enabling infrastructure-a belief that subsequent events in Russia (e.g., the arrest of Khodorkovskii, the revision of the PSA legislation) contributed to strengthening over time, until it eventually rose as the new dominant collective frame of Shell's managers.

Overall, the case of Shell suggests that scenarios are likely to help managers to evolve and adapt their mental models to a changing environment by enabling the rise of a set of dominant beliefs. The case of Shell also suggests that the dominant beliefs that stem from scenarios are likely to depart from mainstream history.

Scenarios and investment decisions. The new dominant beliefs that stemmed from the scenarios had a strong impact on Shell's strategic investments in Russia. Additionally, such investments contributed to the evolution of the scenarios and beliefs themselves.

In the early 2000s, the beliefs about the growing demand for gas and the strategic relevance of the LNG-transportation infrastructure led the company to focus its financial resources on the development of the Lunskoe gas field and the related LNG plant and pipelines (second phase of the Sakhalin II project). In turn, large purchases from target customers in Japan and South Korea reinforced the beliefs about the demand for gas and the market opportunities inherent to LNG; these beliefs subsequently caused Shell to expand Sakhalin II itself and, more generally, its LNG operations. After the acquisition of the BG Group in 2015, Shell has become primarily a gas company and the world's leading producer of LNG. 
Similarly, in 2005, the belief about the growing ambition of the Putin government resulted in the company's decision to enter into a swap agreement with Gazprom. Subsequently, in 2006, the dismissal of Gazprom from the swap agreement and the allegation of ecological damages strengthened the same belief about the growing ambition of the Putin administration, and this belief, in turn, led Shell to renegotiate its partnership with Gazprom.

Overall, the case of Shell suggests that dominant beliefs that stem from scenarios are likely to affect (and be affected by) strategic investment decisions.

\section{Sources of competitive advantage, cognitive attention and interpretation, and adaptation}

Scenarios and sources of competitive advantage. An important feature of Shell's scenarios was the anticipation that the LNG-enabling infrastructure (gas pipeline and LNG plant) on the island of Sakhalin would be a major source of competitive advantage in the Asia-Pacific energy market. Shell's scenarios also anticipated that the growing ambition of the Putin administration could be a major barrier to the achievement of this infrastructure. These anticipations were both correct, i.e., consistent with future competition outcomes in the Russian energy market. Their correctness is well emphasized by the comparison of the performance of Shell with that of the other energy major that tried to establish itself in the country soon after the collapse of the Soviet Union, namely, ExxonMobil.

ExxonMobil entered Russia in 1995, when it signed the PSA governing the Sakhalin I 
project on the island of Sakhalin, i.e., the sister project to Sakhalin II. ${ }^{17}$ While it initially focused on the development of the oil fields, in the mid 2000s, ExxonMobil made plans to build a pipeline and export gas to China, starting in 2010. However, in 2007, the Russian deputy energy minister prevented ExxonMobil from exporting gas by denying the development of the pipelines. A fierce dispute then ensued between Gazprom and ExxonMobil over the sale of Sakhalin I gas, with Gazprom insisting on acquiring all the gas at state-regulated prices (which were considerably lower than export prices). In contrast, ExxonMobil did not accept any proposal from Gazprom and insisted on its plans to export gas.

The dispute lasted until 2013, when Gazprom withdrew its bid for acquiring the Sakhalin I gas, and ExxonMobil considered the option of building its own LNG plant on the southern part of the island for liquefying and shipping gas. A new and ongoing dispute then started between Gazprom and ExxonMobil (backed by Rosneft, its local partner in the Sakhalin I project), when the latter requested permission to use the free capacity of the Sakhalin II pipelines for transporting its own gas up to their designed LNG plant: a request that Gazprom categorically rejected. In 2015, ExxonMobil revised its original plan by postponing the construction of the LNG plant until at least 2023. In the same year, Gazprom offered a new bid to buy the gas produced in the Sakhalin I fields. As of late 2017, the bargaining for the price of the gas is still continuing. ${ }^{18}$

\footnotetext{
${ }^{17}$ Sakhalin I comprised three offshore oil and gas fields, namely, the Chayvo, Odoptu, and Arkutun Dagi fields, in the northeast of Sakhalin, with potential recoverable resources amounting to 2.3 billion barrels of oil and 485 billion cubic meters of natural gas. The project was operated by a consortium led by Exxon Neftgas Limited (ENL), a subsidiary of ExxonMobil. Exxon Neftegas and Japan's Sodeco each have a 30\% stake in the project, whereas Russia's Rosneft and India's ONGC each have a 20\% stake.

${ }^{18}$ Such a deal would benefit not only the Sakhalin II and Sakhalin I consortia but also the Russian Federation. The Sakhalin I partners could fully exploit their existing upstream facilities, while the Sakhalin II
} 
As a result, since 2010, Shell's annual combined production of oil and gas in Russia and Shell's profit have largely exceeded those of ExxonMobil. This difference is exactly due to the production and export of gas: the LNG-enabling infrastructure on the island of Sakhalin indeed represents the ultimate source of competitive advantage that has allowed Shell to establish its leadership in the Asia-Pacific energy market. Similarly, as anticipated by Shell's scenarios, the growing interventionism of the new Putin administration represented the main barrier that the company had to overcome to complete this infrastructure. ${ }^{19}$

Beliefs, cognitive attention and interpretation, and adaptation. Shell's managers' new dominant beliefs about the essential role of the LNG infrastructure and the Putin administration in future competition outcomes were thus correct, i.e., consistent with the real future. These beliefs eventually turned out to be "the alternative paths into the future" that increased the "power of perception" [see previous quotation from A. de Geus] of Shell's managers, i.e., their capability to notice and interpret a wider array of external changes - even if these changes had not been anticipated in the scenarios themselves.

Let us reconsider the arrest of Khodorkovskii, the establishment of Gazprom's monopoly on gas exports, the cost overruns, the allegations of ecological damages, etc.: these events were not predicted by Shell's scenarios. However, when they occurred, Shell's managers could

consortium would use the gas to feed the third production train that it is going to add to its own Sakhalin II LNG plant. The Russian government, in turn, would avoid the additional costs related to the new investments in capital expenditure required for the expansion of Sakhalin I- estimated at $\$ 10-13$ billion.

${ }^{19}$ Although, for the sake of conciseness, we do not describe their cases thoroughly, it is worth mentioning that together with ExxonMobil, other major global energy companies experienced major challenges in Russia when they attempted to enter the local gas market. For instance, British Petroleum (BP) was prevented by Gazprom from exporting gas from its Kovykta field in East Siberia to China, which ultimately caused BP to surrender the property rights to the field to Gazprom. 
distinctly "hear" these unpredicted "signals" because they were "relevant to them" [see previous quotation from A. de Geus], i.e., because they all involved the sources of competitive advantage (gas pipelines and LNG plant) and the barriers to these sources (growing ambition of the Putin government) that they had clear in their minds. The new mental models of Shell's managers directed their cognitive processes of attention and interpretation and enabled them to adapt to the turbulent Russian institutional environment more promptly and effectively than any other foreign energy major. In particular, when new PSAs with foreign companies were eliminated, the exclusive right to export gas was granted to Gazprom, and Khodorkovskii was arrested in 2003, Shell negotiated the swap agreement with Gazprom and its direct involvement into Sakhalin II. Later, when it faced the cost overruns and allegations of ecological damages, Shell accepted the Russian company as the new major shareholder and leader of the project consortium.

Shell's managers made their final decision regarding the deal with Gazprom in less than three months, between September and December 2006. This deal originally raised fierce criticism from industry analysts, as they argued that Shell did not protect its interests. ${ }^{20}$ Analysts were convinced that the environmental inspection findings and the allegations of ecological damages were simply a maneuver by the Russian government. (Indeed, Shell itself firmly denied any negligence and the Putin administration considerably reduced the estimations of ecological damages soon after Gazprom entered the Sakhalin II consortium. Most importantly, at that time, Gazprom did not have the technical expertise to build an LNG plant, and it thereby needed the

${ }^{20}$ See, for instance, Morgan. O. 2007. Sakhalin blow hits Shell's reserves. The Observer 28 January; and Krysiek, T. F. 2007. Agreements from Another Era: Production Sharing Agreements in Putin's Russia, 2000-2007. Oxford Institute for Energy Studies. 
support of Shell to run Sakhalin II, considerably increasing Shell's negotiating power. $)^{21}$

Notably, in 2007, industry analysts compared the capitulation of Shell with the fortunes of

ExxonMobil itself and pointed out that the latter had been much more successful in protecting its strategic assets in the country. ${ }^{22}$

One decade later, however, the final deal with Gazprom proved to be very foresighted and beneficial to Shell. This deal actually provides the most compelling evidence of the importance of the new dominant beliefs that stemmed from scenarios in enhancing the cognitive attention and interpretation of Shell's managers. In April 2017, Ian Craig, Sakhalin Energy's CEO, emphasized that the Gazprom's entry eventually allowed to "end the period of uncertainty." 23 An executive director of Sakhalin Energy echoed:

With the entry of Gazprom as a Sakhalin Energy major shareholder, we are confident that, in cooperation with the Russian Government, we can bring this first Russian frontier LNG project to completion, as scheduled, for delivery of LNG to our customers in Japan, Korea and the United States. ${ }^{24}$

The 2006 Annual report of Sakhalin Energy also emphasized

The key focus for Sakhalin Energy is to complete the project on schedule, allowing LNG to be delivered to existing customers in Japan, Korea and the North American West Coast. All existing LNG sales contracts will remain in force and will be honoured. After the protocol signing ceremony, the Sakhalin Energy shareholders met with President Vladimir Putin in the Kremlin. The Russian leader welcomed the agreement with Gazprom and assured the shareholders that the Russian Government would give full support to the Sakhalin II Project.

In the same report, Shell CEO Jeroen van der Veer commented

${ }^{21}$ Kramer, A. E. 2006. Russia halts pipeline, citing river damages. NYT, 19 September.

${ }^{22}$ See, for instance, Helman, C. 2011. Rosneft deal shows Exxon to be the only supermajor with heft in Russia. Forbes, 31 August; and Lustgarten, A. 2007. Shell shakedown: Fortune's Abrahm Lustgarten reports how the world's second-largest oil company lost control of its $\$ 22$ billion project on Russia's Sakhalin Island. Fortune, 1 February.

${ }^{23}$ Belton, C. 2007. Gazprom takeover of Sakhalin-2 'ends uncertainty'. FT, 19 April.

${ }^{24}$ Gazprom Enters Sakhalin II Project: http://www.prnewswire.com/news-releases/gazprom-enters-sakhalinii-project-58568837.html [18 April 2007]. 
We welcome Gazprom's entry as a project partner and a leading shareholder. The greatest news is that we have stabilised the situation with the project, and all the partners can now work together to get Sakhalin II up and running. This agreement is an important step forward and positions Sakhalin II for further growth opportunities.

These statements demonstrate that when they received the allegations of ecological damages and the licenses were suspended, "the key focus" of Shell's managers' attention was exactly "to complete the project [i.e., the gas pipelines and plant]". The belief that the gas-enabling infrastructure would be a major source of advantage — and the belief that the growing ambition of the Russian government would be a major barrier to this infrastructure—also affected Shell's managers' interpretation of the alternative options available to respond to the allegations. On the one hand, Shell's managers could stand up to the Putin administration, which was indeed the strategic response that ExxonMobil adopted when, in 2007, it was similarly denied the right to build its own pipeline to China. On the other hand, Shell's managers considered a dispute with the Putin administration as more detrimental than the final deal with Gazprom. Even if they eventually had to cut their energy reserves in Sakhalin by half, Shell's top executives interpreted the deal as the best means to "stabilise the situation with the project" and "get Sakhalin II up and running", being "assured that the Russian Government would give full support to the Sakhalin II Project" and positioning "Sakhalin II for further growth opportunities" (e.g., the third train in the LNG plant that Shell and Gazprom decided to build in 2015).

In particular, the statement of Shell CEO van der Veer resembled the words that he used in 2005 when he signed the original swap agreement with Gazprom [see quotation in the previous sections]: Shell's executives had clear in their minds the threat inherent in the growing ambition of the Putin administration — and had focused thereby their attention on the need to fully secure its support—well before they received the allegations of ecological damages. 
Figure 2 summarizes our findings on the relationship among scenarios, managerial beliefs, and adaptation at Shell.

\section{'Insert Figure 2 about here'}

Overall, our findings suggest that managers are likely to develop strong beliefs about the sources of competitive advantage - and the barriers to these sources - that they predict through scenarios. Managers who accurately anticipate future sources of competitive advantage (and related barriers) are more likely to focus their attention on relevant changes in the external environment, understand their impact, and ultimately adapt - even if these changes have not been predicted in the scenarios.

\section{Discussion}

In this paper, we add to the understanding of scenario planning, cognitive dynamics, and strategic investment decisions. Our core contribution is a conceptual framework that illustrates the effects of scenarios on the mental models of top managers and their cognitive processes of attention and interpretation (Ocasio, 1997; Kaplan, 2008a). More generally, we respond to the question of how managerial beliefs originate and evolve over time and how firms can be more successful in managing cognitive adaptation in turbulent environments (Kaplan 2011; Mezias et al., 2001).

Scenario planning and cognitive dynamics 
A growing number of studies in the strategic management literature are moving from the traditional focus on the relationship between managerial beliefs and competition outcomes to the exploration of the cognitive dynamics that occur in organizations and produce such a relationship (Garud et al., 2010; Laamanen and Wallin, 2009; Szulanski et al., 2004). This work portrays cognition as an evolutionary process and shows that the beliefs that managers inherit from prior history are not static. In particular, some scholars have focused on the relationship between scenario planning and managerial beliefs by conducting both theoretical (de Geus, 1988; Wack, 1985) and laboratory (Kuhn and Sniezek, 1996; Meissner and Wulf, 2013; Phadnis et al., 2015; Schoemaker, 1993) studies.

Our research expands this latter work by adopting a longitudinal perspective. We investigate the impact of scenarios upon the mental frames of corporate executives who concretely used scenarios on a continuous and long-term basis and under conditions of extreme uncertainty.

Our findings support the argument that scenario planning can effectively help managers to adapt their mental models to a changing environment. Specifically, the case of Shell's venture in Russia shows that scenario planning contributed to the establishment of a new dominant logic about the sources of competitive advantage and the barriers to these sources - a new dominant logic that departed from the mainstream history of the company and ultimately drove its strategic investment decisions. This is particularly true for the belief about the prominence of gas (and the related enabling infrastructure), as opposed to oil during the mainstream history of the energy business; and the belief about the growing ambition of the Putin administration, as opposed to the friendly support that Shell and other western majors had received from the previous Yeltsin government. 
These new dominant beliefs stemmed from Shell's deductive approach to scenario planning (Schwartz, 1991), which led managers to frame the different lessons learned from prior history around alternative hypotheses about the future and to look for external events that could confirm either of these hypotheses. Our findings demonstrate that if we ignore Shell's scenario planning activities, we cannot fully understand the internal cognitive dynamics in this company, the cognitive processes of attention and interpretation and, eventually, the strategic outcomes in Russia.

Scenario planning, cognition, and investment decisions

By combining research on scenario planning with research on cognition, we add to our understanding of strategic decision making under conditions of extreme uncertainty (Augier et al., 2018; Phadnis et al., 2015).

Our empirical findings suggest that scenarios are unlikely to fully anticipate the future, even in the form of alternative visions. Shell's performance in Russia shows that the likely value of scenarios lies instead in a process of continuous learning that helps managers to adapt more quickly to environmental changes (de Geus, 1997; Schoemaker, 1993). Our work expands our knowledge of the microfoundations, i.e., the underlying mechanisms, of this learning process. Although scenarios cannot accurately predict all major changes and events in the external environment, they can accurately predict future sources of competitive advantage (e.g., in the case of Shell, the pipelines and LNG plant in Sakhalin) and the barriers to these sources (e.g., the growing ambition of the Russian government). Scenarios can thus sharpen managers' ability to notice and interpret external events — even if these events have not been predicted in the 
scenarios. The anticipation of future sources of competitive advantage and, contextually, the accuracy of the beliefs about these sources are the essential conditions through which scenarios contribute to organizational learning and adaptation.

Overall, our findings are consistent with the work of previous scholars who have emphasized the need for flexible approaches to strategic decision making in fast-paced industries (Grant, 2003; Eisenhardt and Sull, 2001). This is particularly the case of research on dynamic capabilities (Teece, 2007). Shell's performance in the Russian gas market shows that scenarios can successfully contribute to the dynamic capabilities of the company to sense, seize, and respond to emerging opportunities and threats. Future research efforts can expand our understanding of the linkage between scenario planning, cognition, and the microfoundations of dynamic capabilities (Hodgkinson and Healey, 2011; Helfat and Peteraf, 2015).

\section{Managerial implications and opportunities for future research}

The relationship among scenarios, dominant beliefs about sources of competitive advantage, and investment decisions has relevant managerial implications.

Our findings show that decision makers are likely to hold strong beliefs about the new sources of competitive advantage that they predict through scenarios. Decision makers who anticipate correctly these sources can thereby benefit from the opportunity to adapt more quickly and effectively to their changing environment, as Shell did in the Russian gas industry. However, managers who fail to anticipate future sources of competitive advantage are likely to constrain their search processes. These managers are likely to develop beliefs that are not correct, i.e., do not accurately represent the future competitive landscape, and increase inertia rather than adaptation. 
A key issue in scenario planning is thus the ability to assess the accuracy of scenarios, with regard to the crucial distinction between scenarios that correctly anticipate future sources of competitive advantage and scenarios that do not make correct anticipations. Real options can be very helpful to make exactly this distinction, as they frame strategic investments at different stages - with each stage giving the right, but not the obligation, to move forward to the next one (Smit and Trigeorgis, 2004; Tong and Reuer, 2007). Indeed, Shell's managers used real options together with scenarios in the Sakhalin II project by developing first the oil fields in 1996, then the gas fields in 2003, and finally by planning to expand the LNG plant in 2015.

We suggest that future research efforts might explore how to combine scenarios and real options to help managers assess the accuracy of alternative assumptions about sources of competitive advantage (Courtney, 2001; Miller and Waller, 2003).

\section{Conclusion}

The aim of this paper is to gain a holistic, longitudinal understanding of scenario planning, cognition, and performance. We studied the exemplar case of a leading firm that used scenarios for several decades to address the growing turbulence of its business environment. Our research setting, data collection and data analysis were designed to enhance the construct and internal validity of our conceptual framework, while we have sought to strengthen its reliability and external validity via data triangulation among different sources (Eisenhardt, 1989).

However, it is critical to note that our work is based on a focal firm and thus on a single case study. We selected our theoretical sample according to the main purpose of this paper, which is to develop theory, as is typical in case study research. Similar investigations of other companies and other industries are needed to provide further evidence for our theoretical 
propositions. The next step is the empirical testing of our emerging constructs (Eisenhardt and Graebner, 2007).

We hope that, despite these limitations, our work might inspire future efforts of scholars and practitioners and help to expand our knowledge about the mutual influences of scenarios, managerial beliefs, and strategic decision making in a changing environment. 


\section{References}

Augier M., Dew N., Knudsen T., Stieglitz, N., 2018. Organizational persistence in the use of war gaming and scenario planning. Long Range Planning, forthcoming.

Barr, P.S., 1998. Adapting to unfamiliar environmental events: A look at the evolution of interpretation and its role in strategic change. Organization Science, 9, 644-649.

Barr, P.S., Stimpert, J.L., Huff, A.S., 1992. Cognitive change, strategic action, and organizational renewal. Strategic Management Journal, 13, 15-36.

Bettis, R., Gambardella. A., Helfat. C., Mitchell, W., 2015. Qualitative Empirical Research in Strategic Management, Strategic Management Journal, 36, 637-639.

Bradfiled, R., Wright, G., Burt, G., Cairns, G., van der Hejden K., 2005. The origins and evolution of scenario techniques in long range business planning. Futures, 37, 795-812.

Charmaz, K., 2006. Constructing grounded theory: A practical guide through qualitative analysis. Sage Publications, Thousand Oaks, CA.

Chattopadhyay, P., Glick, W.H., Huber, G.P., 2001. Organizational actions in response to threats and opportunities. Academy of Management Journal, 44, 937-955.

Cornelius, P., Van de Putte, A., Romani, M., 2005. Three decades of scenario planning in Shell. California Management Review, 48, 92-109.

Courtney, H. 2001. 20/20 Foresight: Crafting Strategy in an Uncertain World. Harvard Business School Press, Boston, MA.

Daft, R.L., Weick, K.E. 1984. Toward a model of organizations as interpretation systems. Academy of Management Review, 9, 284-295.

Davis, G., 2002. Scenarios as a tool for the 21st century. Paper presented at Probing the Future Conference, Glasgow, UK.

de Geus, A., 1988. Planning as learning. Harvard Business Review, 66, 70-74.

de Geus, A., 1997. The living company. Harvard Business School Press, Boston, MA.

Eggers, J.P., Kaplan, S. 2009. Cognition and renewal: Comparing CEO and organizational effects on incumbent adaptation to technical change. Organization Science, 20, 461-477.

Eggers, J.P., Kaplan, S., 2013. Cognition and capabilities. Academy of Management Annals, 7, 293-338.

Eisenhardt, K.M, Sull, D.N., 2001. Strategy as simple rules. Harvard Business Review, 79, 106116.

Eisenhardt, K.M., 1989. Building theories from case studies research. Academy of Management Review, 14, 532-550.

Eisenhardt, K.M., Graebner, M.E., 2007. Theory building from cases: opportunities and challenges. Academy of Management Journal, 50, 25-32. 
Eisenhardt, K.M., Graebner, M.E., Sonenshein, S., 2016. Grand Challenges and Inductive Methods: Rigor without Rigor Mortis. Academy of Management Journal, 59, 1113-1123

Eisenhardt, K.M.,1999. Strategy as strategic decision making. Sloan Management Review, 40, 65-72.

Fiol, C.M., 1990. Explaining strategic alliance in the chemical industry. In A.S. Huff (Ed.), Mapping strategic thought. Wiley, New York, 227-249.

Garud, R., Kumaraswamy, A. Karnøe, P., 2010. Path dependence or path creation?' Journal of Management Studies, 47, 760-74.

Garud, R., Rappa, M.A., 1994. A socio-cognitive model of technology evolution: the case of cochlear implants. Organization Science, 5, 344-62.

Gavetti, G., Rivkin, J.W., 2007. On the origin of strategy: Action and cognition over time. Organization Science, 18, 420-439.

Gilbert, C.G., 2006. Change in the presence of residual fit: can competing frames coexist? Organization Science, 17, 150-167.

Grant, R.M., 2003. Strategic planning in a turbulent environment: evidence from the oil majors. Strategic Management Journal, 24, 491-517.

Grewatsch S., Kleindienst, I., 2017. How organizational cognitive frames affect organizational capabilities: The context of corporate sustainability. Long Range Planning, forthcoming.

Helfat, C., Peteraf, M. 2015., Managerial Cognitive Capabilities and the Microfoundations of Dynamic Capabilities. Strategic Management Journal, 36, 831 - 850.

Hodgkinson, G. P., Healey, M.P., 2011. Psychological foundations of dynamic capabilities: reflexion and reflection in strategic management. Strategic Management Journal, 32, 15001516.

Ingvar, D.H., 1985. Memory of the future: an essay on the temporal organization of conscious awareness, Human Neurobiology, 4, 127-136.

Jackson, S.E., Dutton, J.E., 1988. Discerning threats and opportunities. Administrative Science Quarterly, 33, 370-387.

Kaplan, S., 2008a. Framing contests: strategy making under uncertainty. Organization Science, $19,729-752$

Kaplan, S., 2008b. Cognition, capabilities, and incentives: Assessing firm response to the fiberoptic revolution. Academy of Management Journal, 51, 672-695.

Kaplan, S., 2011. Research in cognition and strategy: Reflections on two decades of progress and a look to the future. Journal of Management Studies, 48, 665-695.

Kaplan, S., Murray, F., Henderson, R.M., 2003. Discontinuities and senior management: Assessing the role of recognition in pharmaceutical firm response to biotechnology. Industrial and Corporate Change, 12, 203-233.

Kaplan, S., Tripsas, M., 2008. Thinking about technology: applying a cognitive lens to technical change. Research Policy, 37, 790-805. 
Kiesler, S., Sproull, L., 1982. Managerial response to changing environments: perspectives on problem sensing from social cognition. Administrative Science Quarterly, 27, 548-570.

Kuhn, K.M., Sniezek, J.A., 1996. Confidence and uncertainty in judgmental forecasting: differential effects of scenario presentation. Journal of Behavioral Decision Making, 9, 231-247.

Laamanen, T., Maula, M., Kajanto, M., Kunnas, P., 2018. The role of cognitive load in effective strategic issue management. Long Range Planning, forthcoming.

Laamanen, T., Wallin, J., 2009. Cognitive dynamics and capability development paths. Journal of Management Studies, 46, 950-981.

Locke, K., 2001. Grounded Theory in Management Research. Sage, London.

Meissner, P., Wulf, T., 2013.Cognitive benefits of scenario planning: its impact on biases and decision quality. Technological Forecasting and Social Change, 80, 801-814.

Mezias, J.M., Grinyer, P., Guth, W.D., 2001. Changing collective cognition: A process model for strategic change. Long Range Planning, 34, 71-95

Miles, M.B., Huberman, A.M. 1994. Qualitative data analysis: An expanded sourcebook, 2nd ed. Sage, Thousands Oaks.

Miller, K. D., Waller, H.G., 2003. Scenarios, real options and integrated risk management. Long Range Planning, 36, 93-107.

Mintzberg, H., 1990. The design school: reconsidering the basic premises of strategic management. Strategic Management Journal, 11, 171-195.

Nadkarni, S., Barr, P.S., 2008. Environmental context, managerial cognition, and strategic action: An integrated view. Strategic Management Journal, 29, 1395-1427.

Nadkarni, S., Narayanan, V.K., 2007. The evolution of collective strategy frames in high- and low-velocity industries. Organization Science, 18, 688-710.

Ocasio, W, Laamanen, T., Vaara, E., 2018. Communication and attention dynamics: An attention-based view of strategic change. Strategic Management Journal, 39, 155-167.

Ocasio, W., 1997. Towards an attention-based view of the firm. Strategic Management Journal, 18, 187-206.

Phadnis, S., Caplice, C., Sheffi, Y., Singh, M. 2015. Effect of scenario planning on field experts' judgement of long-range investment decisions. Strategic Management Journal, 36, 14011411

Porac, J. F., Thomas, H, Wilson, F., Paton, D., Kanfer, A., 1995. Rivalry and the industry model of Scottish knitwear producers. Administrative Science Quarterly, 40, 203-227.

Prahalad, C.K., Bettis, R.A., 1986. The dominant logic: a new linkage between diversity and performance. Strategic Management Journal, 76, 485-501.

Ramirez, R., Selsky, J.W. 2016. Strategic Planning in Turbulent Environments: A Social Ecology Approach to Scenarios. Long Range Planning, 49, 90-102. 
Rerup, C., 2009. Attentional triangulation: Learning from unexpected rare crises. Organization Science, 20, 876-893.

Schoemaker, P.J.H. ,1995. Scenario planning: a tool for strategic thinking. Sloan Management Review, 23, 25-34.

Schoemaker, P.J.H., 1993. Multiple scenario development: its conceptual and behavioral foundation. Strategic Management Journal, 14, 193-213.

Schoemaker, P.J.H., 2004. Forecasting and scenario planning: the challenges of uncertainty and complexity. In Blackwell Handbook of Judgment and Decision Making, Koehler D.J., Harvey, N. (Eds.), Blackwell, Oxford, UK, pp. 274-296.

Schwartz, P., 1991. The Art of the Long View: Planning for the Future in an Uncertain World. Doubleday Currency, New York.

Smit, J.T.J., Trigeorgis L., 2004. Strategic investment: Real options and games. Princeton University Press, Princeton.

Strauss, A., Corbin, J., 1990. Basics of qualitative research: Grounded theory procedures and techniques. Sage, Newbury Park.

Szulanski, G., Doz, Y., Ovetzky, Y., 2004. Incumbents' framing: three established companies respond to the internet. Advances in Strategic Management: Business Strategy Over the Industry Life Cycle, 21, 77-106.

Teece, D.J., 2007. Explicating dynamic capabilities: the nature and microfoundations of (sustainable) enterprise performance. Strategic Management Journal, 28, 1319-1350.

Thomas, J.B., Clark, S.M., Gioia, D.A., 1993. Strategic sensemaking and organizational performance: Linkages among scanning, interpretation, action, and outcomes. Academy of Management Journal, 36, 239270.

Tong T.W., Reuer J.J. 2007. Real Options in Strategic Management, in Reuer J.J., Tong T.W. (Eds.) Real Options Theory. Advances in Strategic Management, 24, 3-28

Tripsas, M., Gavetti, G., 2000. Capabilities, cognition, and inertia: evidence from digital imaging. Strategic Management Journal, 21, 1147-1162.

van der Heijden, K., 1996. Scenarios: The art of strategic conversation. Wiley, New York.

Wack, P., 1985. Scenarios: Uncharted waters ahead. Harvard Business Review, 63, 73-89.

Walsh, J.P., 1995. Managerial and organizational cognition: Notes from a trip down memory lane. Organization Science, 6, 280-321.

Weick, K.E., Sutcliffe, K.M., 2006. Mindfulness and the quality of organizational attention. Organization Science, 17, 514-524.

Wilkinson, A., 2009. Scenarios practices: in search of theory. Journal of Futures Studies, 13, $107-114$.

Wiltbank, R., Dew, N., Read, S, Sarasvathy, S.D., 2006. What to do next? The case for nonpredictive strategy. Strategic Management Journal, 27, 981-998. 
Yergin, D. 1990. The Prize: The Epic Quest for Oil, Money, and Power. Simon \& Schuster. New York.

Yin, R. K. 2003. Case Study Research: Design and Methods, third ed. Sage. Newbury Park. 


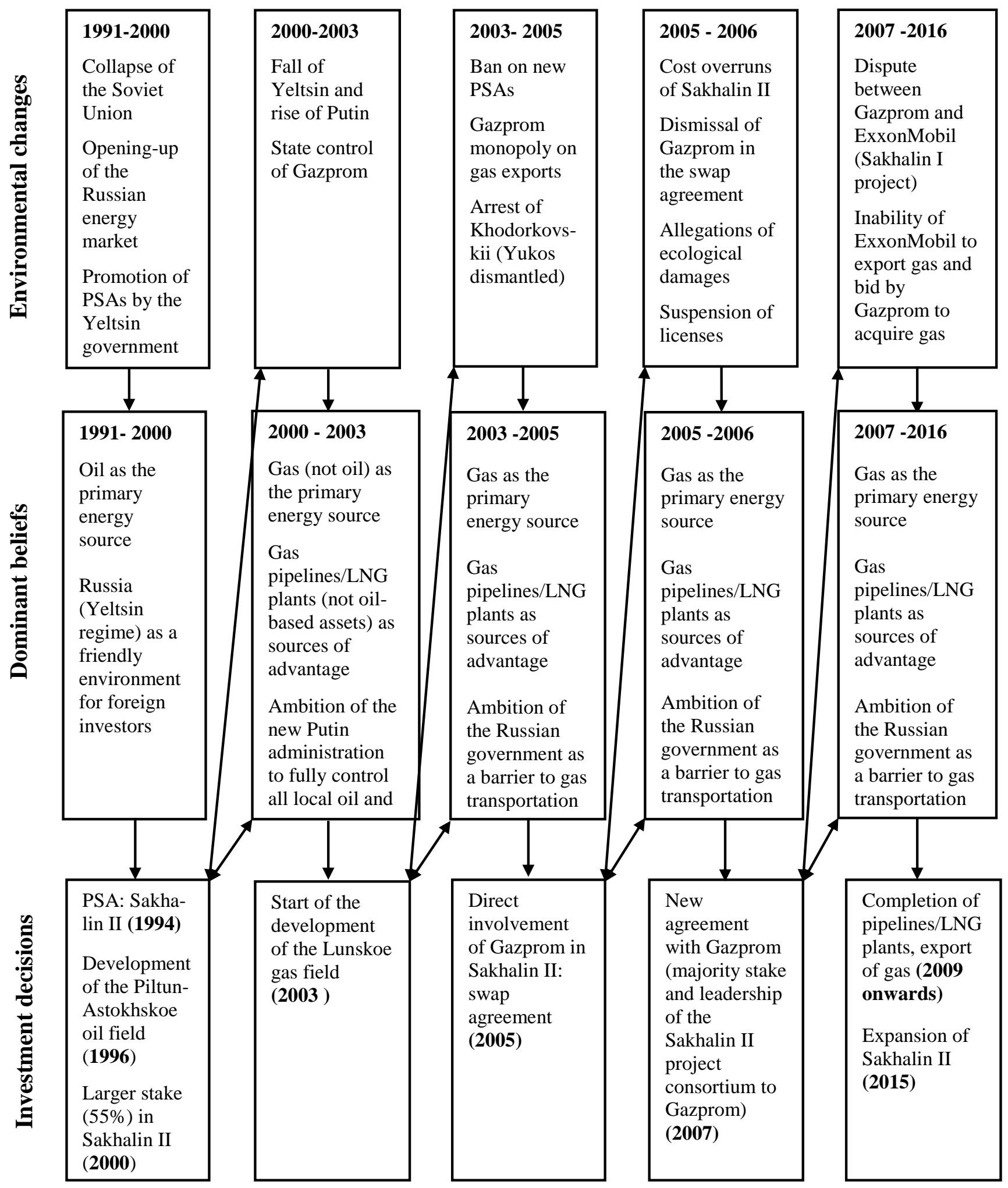

Figure 1. Shell and scenario planning in Russia: Co-evolution of beliefs, environmental changes, and investment decisions 


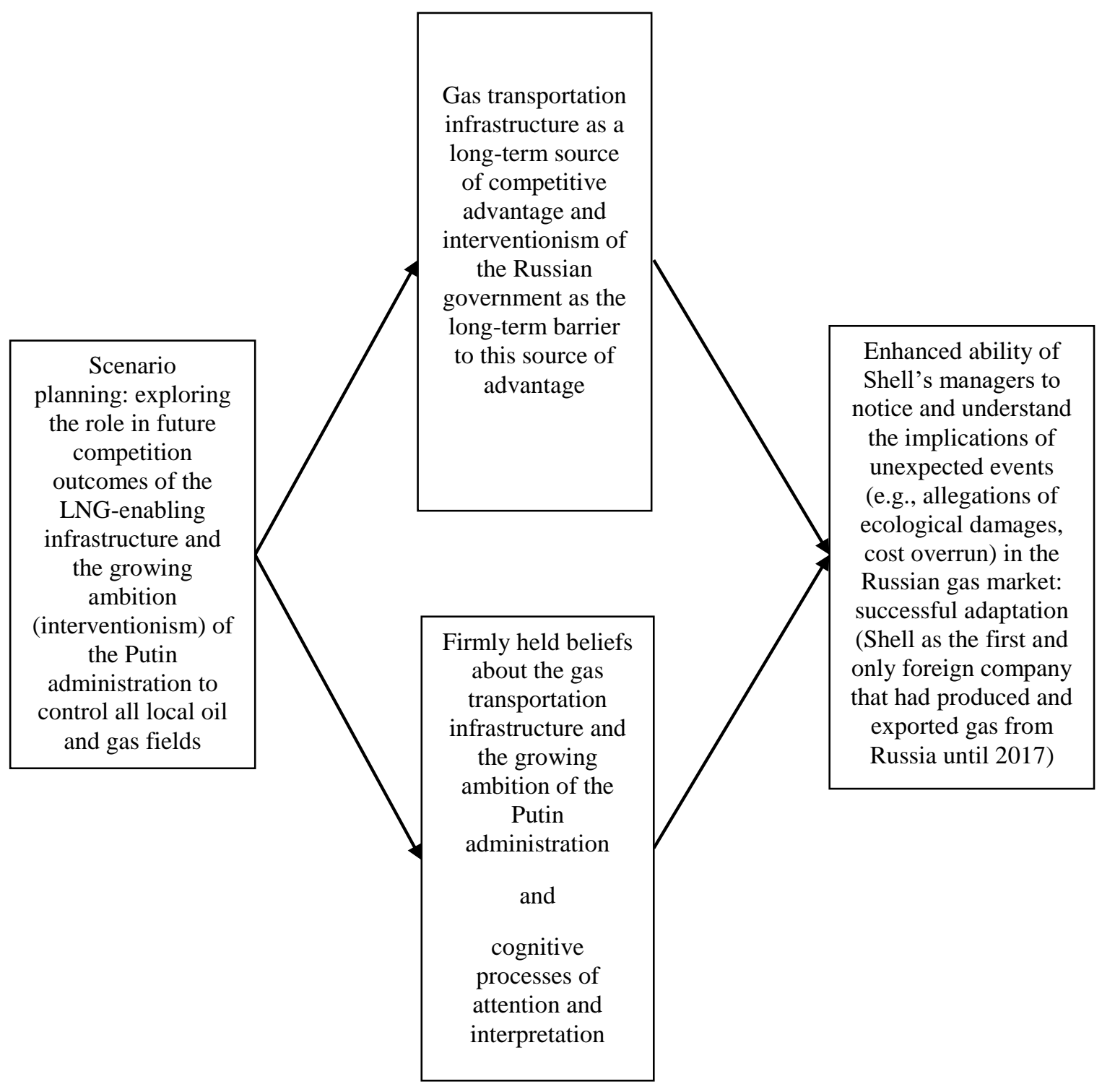

Figure 2. Shell and the Russian energy market: Relationship among scenarios, emerging beliefs about future sources of competitive advantage, and long-term performance 